\title{
Modelling Non-timber Forest Products for Forest Management Planning in Europe
}

\author{
Jari Miina ${ }^{1} \cdot$ Mikko Kurttila $^{1} \cdot$ Rafael Calama ${ }^{2} \cdot$ Sergio de-Miguel ${ }^{3,4} \cdot$ Timo Pukkala $^{5}$
}

Accepted: 13 August 2020 / Published online: 9 October 2020

(C) The Author(s) 2020

\begin{abstract}
Purpose of Review The increased popularity and commercial use of non-timber forest products (NTFPs) calls for the development of models for NTFPs to include their predicted yields in forest management planning and to evaluate the potential of multifunctional forest management. This study assesses and discusses the current state of the art and trends in NTFP yield modelling in Europe and the integration of the models in multi-functional forest management planning at different spatial scales.

Recent Findings Climate-sensitive empirical yield models already exist not only for a variety of NTFPs that are economically important to forest owners (e.g. cork and pine nuts) but also for wild-gathered berries and mushrooms, the harvesting of which cannot be controlled by the forest landowner in all European countries. Several studies on multi-functional forest management planning consider the economic profitability of the joint production of timber and NTFP. Harvesting NTFPs can create significant additional incomes for forest owners, compared with timber production only. However, maximizing the economic returns from the joint production of timber and NTFPs often calls for changes in forest management practices.

Summary Continued efforts in modelling and predicting the yields of NTFPs have enabled forest managers to further expand the analyses of multi-functional forest planning and management in Europe. Climate-sensitive models also allow analyses on the potential effects of climate change on NTFP yields. New models and forest management practices are still needed for tree fruits, birch sap, a wider variety of wild edible mushrooms, specialty mushrooms cultivated on live trees as well as medicinal and edible forest herbs harvested for commercial value in Europe.
\end{abstract}

Keywords Joint production $\cdot$ Multi-functional forest management $\cdot$ Non-wood forest products $\cdot$ Yield models $\cdot$ NTFP $\cdot$ NWFP

\section{Introduction}

The global demand for non-timber forest products (NTFPs) has increased due to the current trends in lifestyle and consumption. As a consequence, the commercial utilization of

This article is part of the Topical Collection on Forest Policy, Economics and Social Research

Jari Miina

jari.miina@luke.fi

Mikko Kurttila

mikko.kurttila@luke.fi

Rafael Calama

rcalama@inia.es

Sergio de-Miguel

sergio.demiguel@udl.cat; sergio.demiguel@ctfc.cat

Timo Pukkala

timo.pukkala@uef.fi
NTFPs is increasing in European forestry $[1 \bullet \bullet, 2 \bullet \bullet]$. Timberoriented forest management is in transition towards sustainable joint-production of timber and NTFPs [3・•] and maintenance of other ecosystem services $[4 \cdot, 5-7]$. Various models for NTFPs have been developed that would enable their

1 Natural Resources Institute Finland (Luke), Yliopistokatu 6 B, 80100 Joensuu, Finland

2 INIA-CIFOR, Forest Research Centre, Ctra A Coruña km 7.5, 28040 Madrid, Spain

3 Department of Crop and Forest Sciences, University of Lleida, Av. Alcalde Rovira Roure 191, 25198 Lleida, Spain

4 Joint Research Unit CTFC, Agrotecnio, Ctra. de St. Llorenç de Morunys km 2, 25280 Solsona, Spain

5 Faculty of Science and Forestry, School of Forest Sciences, University of Eastern Finland, P.O. Box 111, 80101 Joensuu, Finland 
inclusion in forest planning calculations. These models facilitate multi-functional planning where the predicted yields of NTFPs are considered simultaneously with other forest products and services. Recent studies on yield modelling of NTFPs document advances to support the joint production of timber and NTFPs.

There are many different types of NTFPs differing in abundance, ecology, origin, yield periodicity, harvesting rights, frequency and methods, end-use and economic importance. Further, the degree of domestication varies considerably, from wild resources opportunistically collected to products actively enhanced or even cultivated. All these issues bring their challenges to yield modelling and joint management of NTFPs and timber $[8 \bullet]$.

In this review, NTFPs are categorized into four groups as follows $[1 \bullet \cdot]$ : (i) mushrooms and truffles; (ii) tree-origin NTFPs; (iii) understory plants; and (iv) NTFPs of animal origin. NTFPs of tree-origin include exudates (e.g. resin and sap), reproductive propagules (e.g. fruits, nuts and seeds) and vegetative structures (e.g. bark, cork and leaves), among others. The production of these NTFPs is related to several physiological processes of trees, which are complex and partly unknown, and therefore difficult to model. On the other hand, the yields of wild understory berries harvested as NTFPs are more related to growing conditions within the stand, not directly to individual trees. Edible mushrooms of economic interest are mostly mycorrhizal fungi, whose fruit body formation depends on both the physiology of trees and microclimatic conditions controlled by trees.

Animal-based NTFPs are important products in many European countries $[1 \bullet \bullet$. Animal products derived from, for example, game and bees include meat, horns, bones, pelts, glands, feathers, wild honey and beeswax. In addition, various silvopastoral systems may provide beef, milk and many other products [9]. Some NTFPs are derived from game animals that are hunted or trapped as a form of recreation or as a means of species population control. In this review, game-related NTFPs were deliberately excluded as describing gamerelated NTFPs in detail would require a separate review paper.

Depending on the planning objective and NTFP in question, the joint production of timber and NTFP can be studied at different spatial scales: tree, stand, forest holding or region. For example, the yield of pine resin (Pinus pinaster), pine nuts (Pinus pinea) and birch sap (Betula spp.) could be predicted by tree-level models, but the profitability of their production needs to be analysed at a broader level, e.g. stand and landscape. While stand density influences NTFP yields of individual trees [10], and a target density can be identified to maximize tree-level production, a different density may be optimal for stand-level production, which at the end is the objective of the management.

Analyses on sustainable multi-functional forest management may reveal both compatibilities (synergies) and conflicts (trade-offs) between timber production and NTFPs [11, 12]. Full compatibility (lack of trade-off) or incompatibility (timber production prevents the production of NTFP or vice versa) are rare cases. In most cases, NTFPs compete to some extent with timber production, the optimality of joint production depending on the shape of the trade-off curve between timber production and NTFP (Fig. 1). When the trade-off curve is concave, reflecting an increasing rate of transformation, it is often optimal to produce timber and NTFP in the same forest (cases $\mathrm{b}$ and $\mathrm{c}$ in Fig. 1). A decreasing rate of transformation (convex trade-off curve) results in the production of either timber or NTFP (case D in Fig. 1). It should be noted that the shapes of the trade-off curves between timber and NTFP can be different at the forest and stand levels. This is because, at the forest level, production can be directed towards NTFPs to different degrees in different stands, depending on the production potentials of the stands. As a result, the trade-off curves are often more concave in forest level analyses. Full incompatibility at the stand level turns into a negative correlation and straight trade-off curve at the forest level. In addition, the length of the planning period, i.e. time horizon, also affects the shape of the curve.

The objective of this literature review is to describe the recent European advances in modelling NTFP yields and how the developed models have been applied in forest management planning at various geographical scales. The second objective is to discuss the relationships between various NTFPs and timber production. Also, the potential for developing new multiple-use forest management practices is discussed.

\section{Materials and Methods}

We focused our assessment of recent advances in NTFP modelling and the integration of the models in forest management planning based on peer-reviewed research papers published in English from 2010 to 2019. The cut-off date for the review was at the end of January 2020. NTFP models published before 2010 have been reviewed by Calama et al. [8•].

The literature searches were carried out using the Web of Science (WoS) database with the following pre-determined keywords: non-timber OR non-wood forest product AND model OR yield OR forest management. Some additional and more targeted searches were undertaken using terms more directly related to specific NTFPs such as acorn, cork, berry, fruit, honey, leaves, mushroom, nut, resin, sap and truffle, in combination with the previously listed keywords. Search names of the most relevant European NTFPs were identified by using existing literature $[1 \bullet \bullet, 2 \bullet \bullet]$ and our knowledge. All the materials found in the literature search were first checked for relevance for the review, and if judged relevant enough, they were selected for further analyses. Besides the literature 
Fig. 1 Different types of relationships between forest products ranging from full compatibility (a) to different degrees of competition $(\mathbf{b}, \mathbf{c}, \mathbf{d})$. Joint production is the only possibility in case a, probably optimal in cases $\mathbf{b}$ and $\mathbf{c}$, and unlikely optimal in case d. Full incompatibility (not shown) would mean that only one of the two products can be produced. The continuous red line is the trade-off curve. In case $\mathbf{b}$, decreasing the production of a product below the level shown with red dot would also decrease the yield of the other product a

Full compatibility No trade-off

E.g. timber and bark from felled trees

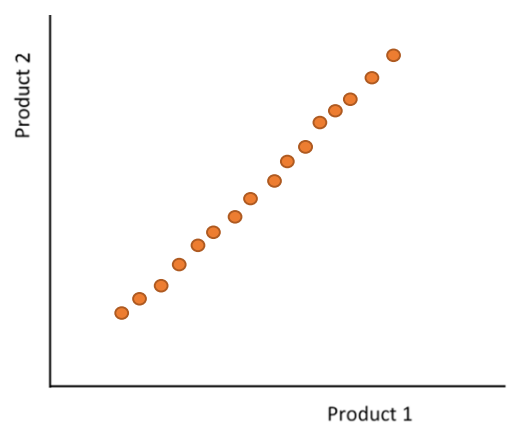

C

Competition and negative correlation Trade-off at all production levels Increasing rate of transformation E.g. bilberry and timber

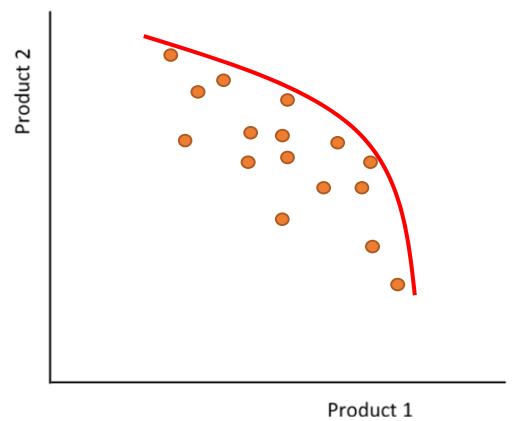

b

Competition and positive correlation Trade-off at near-maximal level Increasing rate of transformation E.g. Boletus edulis and spruce timber

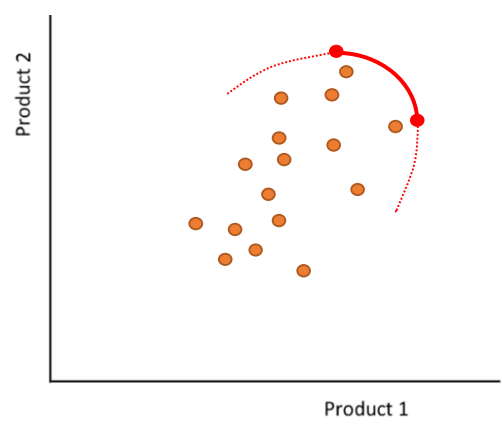

d

Incompatibility, negative correlation Trade-off at all production levels Decreasing rate of transformation E.g. Inonotus obliquus and birch veneer

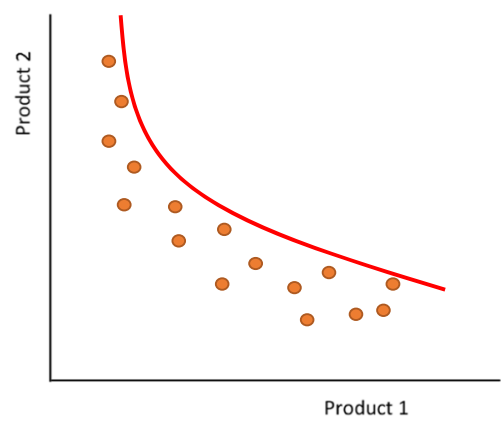

search described above, some additional relevant papers were also found from the references of the analysed papers.

The relevant papers were analysed by extracting the following information to the structured tables of this review: NTFP, species and country of the NTFP, modelling approach as well as the spatial scale of modelling and planning (i.e. tree, stand, forest holding or forest area). The aim was to identify the papers that utilized yield models for NTFPs in multifunctional forest planning calculations at different spatial scales. From these papers, we identified those where the economic profitability of the joint production of NTFP and timber was explicitly studied.

\section{Results}

\section{Models for the Main European NTFPs}

Based on our literature search, a total of 53 NTFP models in 49 peer-reviewed research papers were found within the scientific literature (Table 1, Fig. 2). The number of the NTFP models varied widely among European countries; models were constructed especially in Mediterranean countries and Finland. Many models were prepared for mushroom yields, mainly in Spain, Turkey and Finland. Models were available also for cork (Quercus suber), pine nuts (Pinus pinea) and resin (Pinus pinaster) in Portugal and Spain, and understory berries (Vaccinium myrtillus, Vaccinium vitis-idaea) in Finland. Only a few empirical models were developed for such NTFPs as oak acorns (Quercus spp.), chestnuts (Castanea sativa), laurel leaves (Laurus nobilis), spruce shoots (Picea abies) and truffles (Tuber melanosporum).

Most of the models were empirical, based on the analysis of field-collected data (Table 1). In cases where sufficient empirical data were not available, models based on expert knowledge were developed, for instance for birch sap (Betula spp.) [12] and pine honey (Pinus brutia) [19]. An alternative approach to the assessment of empirical data is to rely on the outcomes of already published models for different geographical areas, growing conditions and observation periods. Such models developed from generated pseudo-data are called meta-models. Meta-models were prepared for 
Table 1 Models for the main European NTFPs published in the 2010s

\begin{tabular}{|c|c|c|c|c|c|}
\hline NTFP & Country & Species & Spatial scale ${ }^{\mathrm{a}}$ & Model type ${ }^{b}$ & Reference \\
\hline \multicolumn{6}{|c|}{ Mushrooms and truffles } \\
\hline \multirow{21}{*}{ Mushrooms } & Spain & Lactarius group deliciosus, Boletus edulis Bull. & Stand & $\mathrm{E}$ & Aldea et al. [13] \\
\hline & Spain & L. group deliciosus, B. edulis Bull. & Stand & $\mathrm{E}$ & Aldea et al. [14] \\
\hline & Spain & Total, edible, marketed & Stand & $\mathrm{EC}$ & Bonet et al. [15] \\
\hline & Spain & L. group deliciosus & Stand & $\mathrm{EC}$ & Bonet et al. [16] \\
\hline & Spain & Various & Stand & $\mathrm{EC}$ & Collado et al. [17] \\
\hline & Europe & Various & Stand & $\mathrm{EC}$ & Collado et al. [18] \\
\hline & Spain & Total, edible, marketed & Stand & $\mathrm{E}$ & de-Miguel et al. [19] \\
\hline & Spain & B. edulis Bull. & Stand & $\mathrm{EC}$ & Hernández-Rodríguez et al. [20] \\
\hline & Spain & Various & Stand & $\mathrm{EC}$ & Herrero et al. [21] \\
\hline & Spain & Total, edible, marketed & Stand & $\mathrm{EC}$ & Karavani et al. [22] \\
\hline & Turkey & L. deliciosus Fr., L. salmonicolor R. Heim \& Leclair & Stand & $\mathrm{EC}$ & Küçüker and Bașkent [23] \\
\hline & Turkey & L. deliciosus Fr., L. salmonicolor R. Heim \& Leclair & Stand & $\mathrm{EC}$ & Küçüker and Başkent [24] \\
\hline & Finland & Marketed, B. edulis Bull., Lactarius spp. & Stand & $\mathrm{E}$ & Kurttila et al. [12] \\
\hline & Spain & L. deliciosus Fr. & Stand & $\mathrm{E}$ & Liu et al. [25] \\
\hline & Spain & Various & Stand & $\mathrm{E}$ & Martínez-Peña et al. [26] \\
\hline & Spain & Total, L. group deliciosus, B. edulis Bull. & Stand & $\mathrm{EC}$ & Martínez-Peña et al. [27] \\
\hline & Germany & Edible & Stand & $\mathrm{EC}$ & Peura et al. [28] \\
\hline & Spain & Total, edible, marketed & Stand & $\mathrm{EC}$ & Sánchez-González et al. [29] \\
\hline & Finland & Marketed, B. edulis Bull., Lactarius spp. & Stand & $\mathrm{EC}$ & Tahvanainen et al. [30] \\
\hline & Spain & Marketed, edible, $L$. group deliciosus & Stand & $\mathrm{EC}$ & Taye et al. [31] \\
\hline & Spain & Edible & Stand & $\mathrm{EC}$ & Vásquez Gassibe et al. [32] \\
\hline Truffles & Spain & Tuber melanosporum Vittad. & Stand & $\mathrm{EC}$ & Ponce et al. [33] \\
\hline \multicolumn{6}{|l|}{ Tree products } \\
\hline \multirow[t]{2}{*}{ Acorn } & France & Quercus petraea (Matt.) Liebl, Q. robur L. & Stand & $\mathrm{EC}$ & Caignard et al. [34] \\
\hline & Spain & Q. canariensis Willd., Q. suber $\mathrm{L}$. & Tree & $\mathrm{EC}$ & Pérez-Ramos et al. [35] \\
\hline Chestnut & Portugal & Castanea sativa Mill. & Region & $\mathrm{EC}$ & Pereira et al. [36] \\
\hline \multirow[t]{7}{*}{ Cork } & Portugal & Q. suber $\mathrm{L}$. & Tree & $\mathrm{E}$ & Almeida et al. [37] \\
\hline & Portugal & Q. suber $\mathrm{L}$. & Tree & $\mathrm{E}$ & Costa et al. [38] \\
\hline & Portugal & Q. suber $\mathrm{L}$. & Tree & $\mathrm{EC}$ & Faias et al. [39] \\
\hline & Portugal & Q. suber $\mathrm{L}$. & Tree & $\mathrm{EC}$ & Faias et al. [40] \\
\hline & Portugal & Q. suber $\mathrm{L}$. & Tree & $\mathrm{E}$ & Paulo and Tomé [41] \\
\hline & Portugal & Q. suber L. & Tree & $\mathrm{EC}$ & Paulo et al. [42] \\
\hline & Italy & Q. suber $\mathrm{L}$. & Tree & $\mathrm{E}$ & Pizzurro et al. [43] \\
\hline Leaves & Turkey & Laurus nobilis L. & Stand & $\mathrm{E}$ & Ayanoğlu et al. [44] \\
\hline \multirow[t]{3}{*}{ Pine nuts } & Spain & Pinus pinea $\mathrm{L}$. & Tree & $\mathrm{EC}$ & Calama et al. [45] \\
\hline & Spain & P. pinea $\mathrm{L}$. & Tree & $\mathrm{EC}$ & Calama et al. [10] \\
\hline & Portugal & P. pinea $\mathrm{L}$. & Tree & $\mathrm{EC}$ & Rodrigues et al. [46] \\
\hline \multirow[t]{7}{*}{ Resin } & Finland & Picea abies (L.) H. Karst., Pinus sylvestris L. & Tree & $\mathrm{E}$ & Kurttila et al. [12] \\
\hline & Portugal & Pinus pinaster Aiton. & Tree & $\mathrm{E}$ & Palma et al. [47] \\
\hline & Greece & Pinus halepensis Mill. & Tree & $\mathrm{E}$ & Spanos et al. [48] \\
\hline & Spain & P. pinaster Aiton. & Tree & $\mathrm{E}$ & Rodríguez-García et al. [49] \\
\hline & Spain & $P$. pinaster Aiton. & Tree & $\mathrm{EC}$ & Rodríguez-García et al. [50] \\
\hline & Spain & P. pinaster Aiton. & Tree & $\mathrm{E}$ & Rodríguez-García et al. [51] \\
\hline & Spain & $P$. pinaster Aiton. & Tree & $\mathrm{E}$ & Rodríguez-García et al. [52] \\
\hline
\end{tabular}


Table 1 (continued)

\begin{tabular}{|c|c|c|c|c|c|}
\hline NTFP & Country & Species & Spatial scale $^{a}$ & Model type ${ }^{b}$ & Reference \\
\hline Sap & Finland & Betula spp. & Tree & $\mathrm{EO}$ & Kurttila et al. [12] \\
\hline Shoots & Finland & P. abies (L.) H. Karst. & Tree & $\mathrm{E}$ & Kurttila et al. [12] \\
\hline \multicolumn{6}{|c|}{ Understory plants } \\
\hline \multirow[t]{5}{*}{ Berries } & Finland & Vaccinium myrtillus L., Vaccinium vitis-idaea L. & Stand & $\mathrm{E}$ & Kilpeläinen et al. [53] \\
\hline & Finland & V. myrtillus L., V. vitis-idaea L. & Stand & $\mathrm{MD}$ & Kurttila et al. [12] \\
\hline & Finland & V. myrtillus L. & Stand & $\mathrm{E}$ & Pukkala et al. [54] \\
\hline & Finland & V. vitis-idaea $\mathrm{L}$. & Stand & $\mathrm{E}$ & Turtiainen et al. [55] \\
\hline & Finland & V. myrtillus L. & Stand & $\mathrm{E}$ & Turtiainen et al. [56] \\
\hline \multicolumn{6}{|c|}{ Animal origin } \\
\hline \multirow[t]{3}{*}{ Tree honey } & Turkey & Pinus brutia Ten. & Stand & $\mathrm{EO}$ & de-Miguel et al. [57] \\
\hline & Romania & Tilia tomentosa Moench. & Region & $\mathrm{E}$ & Ion et al. [58] \\
\hline & Slovenia & $\begin{array}{l}\text { Tilia spp., C. sativa Mill., P. abies (L.) H. } \\
\text { Karst., Robinia pseudoacacia L. }\end{array}$ & Region & $\mathrm{E}$ & Prešern et al. [59] \\
\hline
\end{tabular}

${ }^{\text {a }}$ Spatial scale: predictions at tree, stand or region level

${ }^{\mathrm{b}}$ Model type: $E$ empirical model, $E C$ empirical model including climatic factors, $E O$ expert-opinion model, $M D$ meta-data model fitted to various datasets

understory berries, because several empirical and expertopinion models already exist for Vaccinium myrtillus and V. vitis-idaea in Finland [12].

The spatial scale (tree, stand, forest holding or region) at which the predictions of NTFP models are calculated depends on the nature of the NTFP (Table 1). Therefore, it is logical to model the yield of tree-origin NTFPs (cork, nuts, sap, resin, etc.) at the tree level, and the yield of mushrooms and understory berries at the stand level. In principle, it is possible to estimate all NTFPs at larger scales, i.e. forest holding and region levels. The regional calculations are particularly interesting for NTFPs whose yields are affected by landscape-level characteristics. For example, modelling the tree honey production $[58,59]$ at the landscape level is interesting, because the sources of honeybee forage (tree species providing nectar or honeydew flow) are distributed over a larger area.

A common feature for several NTFPs is the interannual variation in their yields. The between-year variation in yield can be modelled as a function of climatic factors such as monthly mean temperature and precipitation. The significance of climatic factors in predicting NTFP yields is revealed by the fact that about half of the models had climatic variables as predictors (Table 1). This is true particularly with models for mushrooms and pine nuts, the yields of which are sensitive to
Fig. 2 The development of the number of NTFP models and forest management studies published from 2010 to 2019. The cut-off date for the review was the end of January 2020

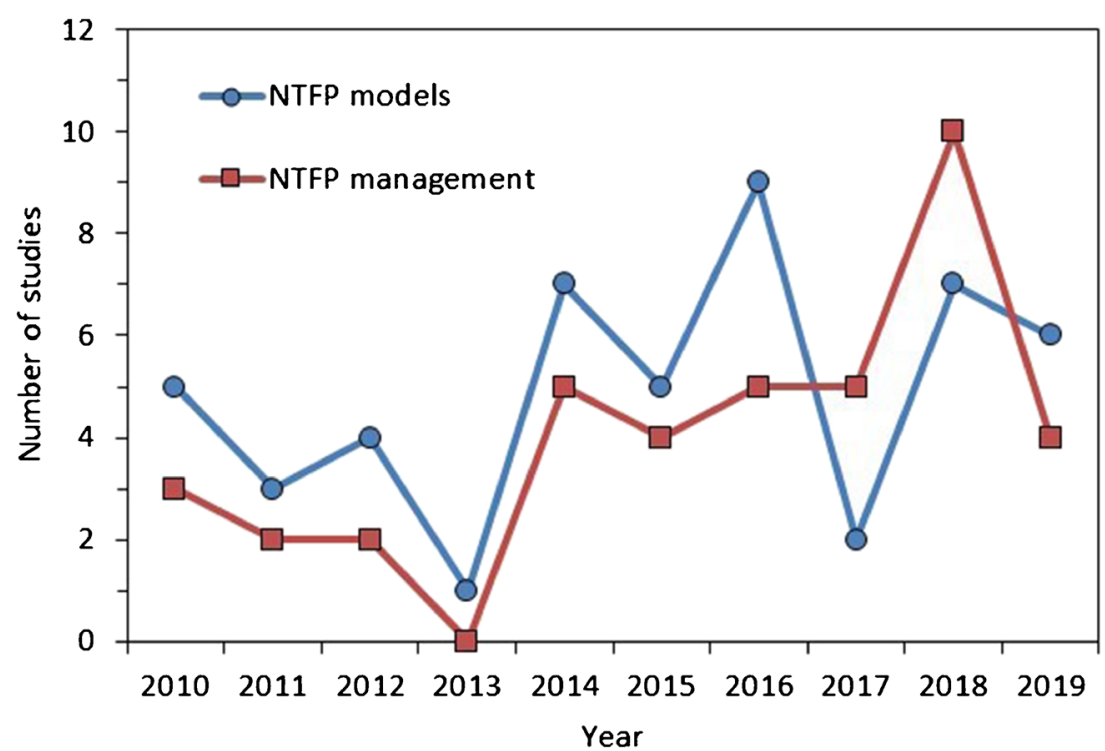


the weather conditions of the previous and/or current growing seasons. In addition, temporal self-regulatory processes, regulating the production in a given time as a function of the production in a previous period (e.g. masting in plant fruit production due to resource depletion following an abundant crop), have also been considered in NTFP models [10].

\section{Compatibility of the Production of NTFPs with Timber}

A total of 46 analyses were conducted on multi-functional forest management planning at different spatial scales in 40 peer-reviewed research papers published during 2010-2019 (Table 2). The publication rate of NTFP models and management practices has fluctuated but increased slowly during the surveyed 10-year period (Fig. 2). In approximately half of the analysed papers (22 out of 40 papers), the economic profitability of the joint production of timber and NTFP was explicitly studied (Table 2 , marked with $€$ ). The economic contribution of NTFPs was analysed equally at both stand and regional levels.

Multi-functional forest planning calculations were undertaken, for instance, for mushrooms in Spain [13, 14, 60], Turkey [62, 63] and Finland [61, 64], pine honey in Turkey [57], understory berries in Finland [54, 64, 79, 80, 84], as well as cork [68-72] and pine nuts [74-77] in Spain and Portugal. In almost all cases, the production of timber and NTFPs (e.g. mushrooms, chestnuts, cork, pine nuts, berries and pine honey) was in synergy in the sense that modified forest management and NTFP harvesting was shown to create significant additional incomes to forest owners. As a result, the total incomes of the joint production were higher than that of timber production only.

Producing some tree-origin NTFPs may however conflict with timber production. For example, harvesting resin and sap negatively affects the growth and quality of timber, and the harvesting of trees directly decreases the production possibilities of these NTFPs. So far, the economic profitability of the joint production of timber with resin or sap has not been studied.

The production of more than one NTFP was simultaneously considered in cases where several NTFPs could be harvested from the same stand or forest area. Examples of considering simultaneously several NTFPs in stand-level optimisation of multi-product forest management include timber with two understory berry species [80] and timber with two mushroom species [61]. Kurttila et al. [12] presented analyses describing simultaneous production for twelve NTFPs, and there are landscape-level analyses that consider two understory berries together with one mushroom species $[64,65]$. In addition, Martins et al. [66] studied how the productivity of both chestnuts and edible mushrooms could be increased in chestnut orchards in Portugal.

\section{Discussion}

\section{Recent Advances in Modelling and Applying NTFP Yields in Europe}

The number of models for NTFPs in Europe has increased considerably since Calama et al. [8•] published a review on modelling European NTFPs in 2010. However, modelling efforts are concentrated in the northern and southern extremes, while models in Central Europe, regardless of considerable forest resources and important NTFPs, are still few.

According to our literature search, mushroom yields were the most commonly modelled NTFPs. In Spain, Turkey and Finland, mushrooms such as Boletus edulis and Lactarius group deliciosus are especially valued, and thus, models that describe the influence of different factors on mushroom yields were fitted and applied in forest planning and optimisation analyses. In addition, models for the total yield of marketed, edible or all mushrooms were also developed. However, species-specific models are still lacking for most edible mushroom species. Several models were also available for other NTFPs that are highly valued in Europe including [2••] cork, pine nuts and resin mainly in Portugal and Spain, as well as understory berries in Finland.

Modelling was focused not just on those NTFPs that are economically important to forest owners (e.g. cork and pine nuts), but also on berries and mushrooms opportunistically collected and whose harvesting cannot be controlled by forest owners in the Nordic countries due to so-called everyman's rights [85]. These NTFPs are socially, culturally and recreationally valuable since they increase the health and well-being of people in many ways [86]. Therefore, multifunctional forest management practices would be needed for the forests where these NTFPs occur. In addition, it is possible that in forests that are intensively utilized for collecting NTFPs their production will be subsidized in the future. For example, it is possible to also develop payments for environmental services (PES) schemes for NTFPs [87], where collectors pay entrance fees, which are then given as compensation for the land-owners if they manage their forests in a way that favours NTFP production. Such payments are already used for mushroom picking permit in Italy [88] and Spain [89] as well as for voluntary forest biodiversity maintenance in Finland (the Forest Biodiversity Programme METSO, https://www.metsonpolku. fi/en-US) and may be used for carbon sequestration in the future. The compensation that owners receive in the METSO programme is based on the value of growing stock and the market price of timber. Development of business models, marketing channels and new innovative NTFP variants may also enhance the trade of NTFPs in the future. Therefore, NTFPs currently within everyman's rights have option value, which makes it unwise to manage the forest in such a way that the possibilities to produce NTFPs are severely diminished. 
Table 2 Summary of studies published in the 2010s in which the NTFP yield models were used in multi-functional planning calculations at different spatial scales. Studies on the economic profitability of the joint production of NTFP and timber are indicated by $€$

\begin{tabular}{|c|c|c|c|c|}
\hline \multirow[t]{2}{*}{ NTFP } & \multicolumn{4}{|l|}{ Level of analysis of management } \\
\hline & Tree & Stand & Forest holding & Landscape \\
\hline \multicolumn{5}{|c|}{ Mushrooms and truffles } \\
\hline Mushrooms & & $\begin{array}{l}\text { Bonet et al. [16] } \\
\text { Collado et al. [17] } \\
\text { Hernández-Rodríguez et al. [60] } € \\
\text { Herrero et al. [21] } \\
\text { Tahvanainen et al. [61] } €\end{array}$ & Kurttila et al. [12] & $\begin{array}{l}\text { Aldea et al. [13, 14] } € \\
\text { de-Miguel et al. [19] } \\
\text { Küçüker and Başkent }[62,63] € \\
\text { Lanzas et al. [7] } \\
\text { Peura et al. [64] } € \\
\text { Peura et al. [65] } \\
\text { Roces-Díaz et al. [5, 6] }\end{array}$ \\
\hline \multicolumn{5}{|l|}{ Tree products } \\
\hline Chestnut & & Martins et al. [66] $€$ & & \\
\hline Cork & Costa et al. [38] & $\begin{array}{l}\text { Pasalodos-Tato et al. [67] } € \\
\text { Paulo and Tomé [68] } €\end{array}$ & $\begin{array}{l}\text { Costa et al. [69] } € \\
\text { von Essen et al. [70]€ }\end{array}$ & $\begin{array}{l}\text { Borges et al. [71] } € \\
\text { Palma et al. [72] }\end{array}$ \\
\hline Pine nuts & & $\begin{array}{l}\text { Ovando et al. [73] } € \\
\text { Pardos et al. [74] } € \\
\text { Pasalodos-Tato et al. [75] } €\end{array}$ & Pereira et al. [76] $€$ & \\
\hline Resin & $\begin{array}{l}\text { Génova et al. [77] } \\
\text { Rodríguez-García et al. [51, 52] }\end{array}$ & & Kurttila et al. [12] & \\
\hline Sap & & & Kurttila et al. [12] & \\
\hline Shoots & & & Kurttila et al. [12] & \\
\hline \multicolumn{5}{|c|}{ Understory plants } \\
\hline Berries & & $\begin{array}{l}\text { Miina et al. }[78,79] € \\
\text { Pukkala et al. }[54] €\end{array}$ & $\begin{array}{l}\text { Kurttila et al. [12] } \\
\text { Pukkala [80] }\end{array}$ & $\begin{array}{l}\text { Eyvindson et al. [81, 82] } \\
\text { Kilpeläinen et al. [83] } € \\
\text { Peura et al. [64] } € \\
\text { Peura et al. [65] } \\
\text { Pohjanmies et al. [84] }\end{array}$ \\
\hline \multicolumn{5}{|c|}{ Animal origin } \\
\hline Tree honey & & de-Miguel et al. [57] $€$ & & \\
\hline
\end{tabular}

Surprisingly, only three models were found for tree fruits (e.g. wild cherries, Prunus spp.) and nuts (e.g. acorns, Quercus spp; chestnuts, Castanea sativa; hazelnuts, Corylus avellana and walnuts, Juglans regia) although they are desired NTFPs especially in Central Europe [2••]. According to Tomé et al. [90], the joint production of timber and fruits or nuts is sometimes impractical due to the high value timber of tree species yielding these products. Furthermore, yield models and joint-management regimes for tree fruits and nuts may not be needed because the main part of the commercial production of these NTFPs is obtained from highly domesticated cultivated or productive plantations, where timber is not considered a significant output and shoot architecture is manipulated by, e.g. pruning and bending.

NTFPs of animal origin, for example, game and bees are also important products in many European countries [1••]. Models for tree honey were found in pine forests in Turkey [57], silver linden (Tilia tomentosa) forests in Romania [58] and linden (Tilia spp.), chestnut (Castanea sativa), spruce (Picea abies) and black locust (Robinia pseudoacacia) forests in Slovenia [59]. In this review, we omitted game animals and silvopastoral systems from the context of NTFP studies. For example, selective cuttings and set-aside wildlife thickets have been adapted to Finnish forest management to accommodate the habitat requirements of forest grouse species whose populations have declined mainly due to unfavourable changes in forest structure caused by intensive forest management [91]. Similarly, effective population control and forest management methods that increase forage availability within the landscape are needed to reduce the conflict between high ungulate densities desired by hunters and browsing damage to trees [92].

Almost all NTFP models were fitted using empirical field data and half of the models, particularly those for mushrooms, utilized climatic factors as predictors. Climatic conditions also affect the growth of trees and thus indirectly the yield of NTFPs that originate from trees. Of course, the weather events are unknown when predicting the future NTFP yields, but in simulation studies, climatic explanatory variables allow the analysis of potential effects of climate change scenarios on NTFPs. Using climatic variables as predictors sometimes makes it easier to 
simulate stochastic annual variation in NTFP yields, which may improve the realism of optimisations and predictions of harvestable yields [61].

If empirical measurements do not exist, are too expensive or few, expert-opinion modelling could be used. For example, in models for birch sap [12] and pine honey [57], expert knowledge on the relationship between tree characteristics and NTFPs were derived and described in the form of mathematical models. Expert-opinion modelling is usually considered as a temporary solution until enough data for empirical modelling are available.

Meta-modelling was also introduced in modelling NTFP yields when the features of several existing berry models were combined to provide more generalized information on berry yields in Finland [12]. The metadata and meta-modelling approach could be more widely considered in utilizing the existing datasets and models for European NTFPs. As an example of such large-scale analyses, Collado et al. [18] studied the relationships among mushroom productivity, tree growth and climatic factors across Mediterranean, temperate and boreal regions in Europe.

Climate change will also affect the yields of NTFPs - some species may benefit, and some suffer from future changes. It is necessary to develop sustainable forest management practices to improve the resilience of forests so that the future existence of NTFPs is considered and warranted alongside with other ecosystem services. For example, the simulation results of Herrero et al. [21] showed that in wetter-than-average scenarios, high thinning intensities had a positive impact on mushroom productivity in Mediterranean pine forests in Spain, while in hotter and drier scenarios the impact was negative. Calama et al. [93] showed how future climate scenarios would result in a reduction in both timber and cone production and how this decline could be alleviated by moving from the current forest management to adaptive management that focuses more on early and intensive thinning and extends rotation lengths. To adapt forest ecosystems to changing conditions, forest management practices should minimize the potential negative effects of climate change on the forests.

More frequently than before, models for NTFPs utilize information describing climatic and site conditions to explain the temporal and spatial variation in NTFP yields. However, some research needs for modelling NTFPs are still the same as mentioned by Calama et al. [8•] 10 years ago. Data scarceness can be pointed out as one of the main factors limiting the modelling of fruits, nuts, sap and some valuable specialty mushrooms. In addition, NTFP models are rare or missing in some parts of Europe. A shortcoming is still the fact that the existing models predict mainly the yield without considering the quality of the product (nut weight, chemical contents of resin, texture and colour of mushrooms, pest damages, etc.). In addition, models usually predict the biological yield although the harvestable or economically usable yield might be more important in forest management planning.

Besides model simulations, field experiments should also be established to confirm the effects of forest management on NTFPs. For example, the effect of thinning on berries [79], mushrooms [61] and pine nuts [74, 75] has been described through the change in stand density, without explicit separation of the effects of thinning treatment and stand density. However, field experiments are costly, time-consuming and complex due to laborious monitoring work and uncontrolled environmental conditions in forests. As an example, MorenoFernández et al. [94] modelled the effect of thinning on cone and pine nut production using a specific thinning trial. In plantations, Martins et al. [66] studied the productivity of chestnuts and edible mushrooms using the experimental trial.

\section{Relationships Between Various NTFPs and Timber Production}

The joint production of timber and NTFPs has been found to result in positive outcomes because of the concave trade-off curve between timber and NTFP (cases b and c in Fig. 1). However, cutting trees that produce NTFPs of tree-origin seldom enhances joint production, except when the NTFPs are harvested from young trees only (e.g. spruce shoots). Harvesting NTFPs with a negative impact on timber quality or yield, for example, resin and sap tapping, conflicts with timber production (case D in Fig. 1). The economic profit of resin and sap production can, however, be higher than the economic loss associated with decay on timber production or quality. In these situations, the forest owners need to prioritize which products they want to mainly produce in their forests.

The production of NTFPs like mushrooms, chestnuts, cork, pine nuts, berries and pine honey may increase the overall profitability of the stand management. In some cases, the value of harvested NTFP can be higher than the value of harvested timber [60]. According to Palahí et al. [95] and PasalodosTato et al. [75], the management of Mediterranean pine stands was unprofitable without the additional incomes from mushrooms and pine nuts, respectively. Also, valuing northern understory berries remarkably modified the optimal timberoriented stand management towards promoting berries, and the joint production of timber and berries was more profitable than timber production [79].

As an exceptional result, both the optimal management of a Picea abies stand and the economic profit were found to be almost the same in timber production and in the joint production of timber and mushrooms [61]. This is because mushroom production conflicted with timber production only at near-maximal level (case B in Fig. 1), since both timber production and mycorrhizal mushrooms benefit from good vigour and growth of trees [15]. 
Cork oak wood is rarely used as timber because it is economically invaluable [67]. However, cutting trees from dense stands increases the growth of remaining trees and consequently cork yield. Due to the high value of cork, the management of cork oak forests is highly regulated. For example, in Portugal, it is forbidden to fell mature cork oaks, and only dead trees are cut. Thus, directing management towards timber production is not even possible in Portuguese cork oak forests. Models for cork oak growth and cork yield have been used in decision support systems to optimize only the cork extraction schedule, not timber production (except in [67]).

The above-described studies are examples that aim at finding out how forest stands could be managed for the joint production of NTFPs and timber. Holding-level calculations can be used to reveal stands where NTFP or timber-oriented management or joint production would be optimal. As a result, forest management would be modified firstly in stands that are the most suitable for NTFPs. For example, Pereira et al. [76] defined the stands within a given forest area where the optimal management could be oriented towards timber or pine nut production. They noticed that the area allocated to pine nuts should be notably larger than it is currently.

Within a forest area, the competitive relationships between timber and NTFPs are due to several reasons. Many NTFPs are directly collected from a certain tree species (pine resin and birch sap), are in a symbiotic relationship with a certain tree species (Boletus edulis with Picea abies) or are indirectly depending on the existence of a certain tree species (understory berries prefers pine stands). As some NTFPs are collected in young (spruce shoots and laurel leaves) or mature stands (cork, mycorrhizal fungi, pine nuts, resin and sap), the NTFP harvest depends on the age-class structure of the forest. Cuttings, especially those aiming at forest regeneration, may therefore have a great impact on NTFPs. Similarly, management promoting certain NTFPs may decrease the profits from timber production. For example, while the production of stone pine cones is maximized at ages of over 150 years, timber quality at these stand ages is severely reduced due to the infection by Phellinus pini [96].

However, some NTFPs benefit from cuttings, and tradeoffs between cutting removals and the yields of NTFPs may exist only at cutting levels near the maximum $[12,61,71]$. Because the spatial distribution of NTFPs varies within the forest area, also the effect of scale (stand, municipality, region, nation) on the compatibility of the production of NTFPs with timber is an important aspect to consider [5-7]. In general, more information on the competitive features among timber and NTFPs is still needed.

\section{Potential for Developing New Multi-functional Forest Management Practices}

This review consisted of peer-reviewed research papers published during the 2010s. First NTFPs that were modelled before the 2010s were largely linked with the industrial use and regulated collection (e.g. cork or pine nuts) [8•]. Thus, it was expected that a lower number of new models for these products would be found in this study. Mushroom yields were frequently modelled in the 2010s, but we expect intensified focus on other NTFPs in the future. According to the survey questionnaire disseminated to countries across Europe by the COST Action FP1203, there are more datasets and models for NTFPs than identified by our literature search [97••]. This indicates that more NTFP models exist which are not published in English or published in non-reviewed journals.

Utilizing the existing datasets and models is an opportunity for developing management instructions for European multiple-use forests and the production of NTFPs. The implementation of NTFP models in forestry-related decision support systems will further facilitate the use of the models by the end-users, bridging the gap between researchers and practitioners. In many cases, the upscaling of the existing NTFP models is also needed for obtaining predictions and supporting decision- and policy-making at regional and national scales. As examples, Pasalodos-Tato et al. [98] estimated the cork production in Spain using the national forest inventory data, Vauhkonen [99] assessed the suitability of forests for berry picking in Finland using airborne laser scanning data, and Schneider et al. [100] predicted stone pine cone production in Spain using terrestrial laser scanning data.

Forest management practices are largely missing for various NTFPs, for example, for birch sap and specialty mushrooms like pakuri (Inonotus obliquus, the sterile conks of which are considered as functional food) and truffles [97••]. Birch sap is tapped in many European countries and cultivation of pakuri is increasing in Finland, even though empirical yield models and information on their future yields are still missing. The need for this information is further highlighted because sap tapping and artificial inoculation with Inonotus obliquus injure the wood, which will become discoloured and finally decayed. As a result, sap and pakuri production conflict with timber production, but sap tapping and pakuri cultivation may be more profitable than timber production.

Truffles are one of the few cultivated mycorrhizal fungi; the roots of planted oak (Quercus spp.) seedlings and some other tree species are inoculated with Tuber spp. spores. Yield models and management practices for truffle production are under development since several years must pass before the oaks begin to produce truffles. On intensively managed truffle plantations, the trees are pruned, soil fertility maintained, weeds controlled, and the ground prepared for good aeration and watered for a sufficient water supply [33]. However, truffle plantations largely differ in the yield and age at which they start producing [101]. Thus, the management of truffle-producing plantations in different growing conditions needs to be further studied.

Some other NTFPs are also taking the first steps from wild resources to domestication. In agroforestry systems or 
pastures, planting mycorrhized trees could promote wild mushroom production [102•]. Similarly, the recent joint use of clonal selection and grafting in Pinus pinea will improve pine nut yields by both increasing cone weight and seed weight per cone and bringing forward the onset of cone production [103]. The effects of silvicultural practices on wild mushroom and pine nut yields have been widely evaluated (Tables 1 and 2), but the current knowledge about the productive potential of intensively managed plantations is still limited.

So far, only a few studies have been conducted on the potential use of mixed-species and continuous cover forestry (CCF) to mitigate the potential conflicts among different ecosystem services, including NTFPs. This is mainly due to a lack of yield models for mixed and uneven-aged forests. At the stand level, timber and berry production has been studied in mixed pine, spruce and birch stands [78, 79], and even-aged rotation forest management (RFM) and CCF have been compared for berry [54] and cone (pine nuts) production [104]. At the holding and landscape levels, the performance of RFM and $\mathrm{CCF}$ has been analysed in the production of berries [80-82].

The results of the review indicated that timber-oriented forest management, especially if targeted to single-tree species and even-aged management, needs to be modified if the aim is to jointly consider NTFPs and other forest products. Responding to the needs to diversify the outcomes from forests and their resilience, forest management planning needs to entail combined objectives. Most of the studies on multifunctional forest management revealed synergies for joint production of NTFPs and timber. In case of possible conflicts, trade-offs need to be further assessed to improve the forestrelated decision-making. NTFPs can be more than just a byproduct of timber production, if synergies are properly understood and utilized in multi-functional forest management [90].

Our review exclusively focussed on a European context. However, NTFPs are utilized globally $[3 \bullet \bullet, 105]$ and especially in many developing, tropical and sub-tropical countries, where NTFPs are gathered from natural forests and their importance to rural livelihoods is remarkably high as they are used for health and nutritional needs and income generation [106]. In these countries, the socio-economic contribution of NTFPs has been extensively studied [106] and NTFP and timber production have usually been dealt with separately [107]. Several models for the NTFP yields have been developed for forest management planning purposes also outside Europe. Models are available for several important NTFPs, for instance pine nuts (Pinus koraiensis) [108], cork [109], rattan (Calamus caesius) [110], bamboo (Yushania alpina) [111], rubber (Hevea brasiliensis) [112], pods (Prosopis caldenia) [113], cranberry (Vaccinium macrocarpon) [114], medicinal plants [115] and maple syrup (Acer saccharum) [116]. The modelling work done in Europe and elsewhere shows how
NTFPs can be considered in forest management planning to evaluate the potential of multi-functional forest management.

\section{Conclusions}

Quantitative analyses describing how forest management affects the provision of various ecosystem services, including NTFPs, call for yield models that are integrated in forest planning systems. Due to increased importance of NTFPs and prevailing dominance of timber production-oriented management, predicted NTFP yields have been mainly used in scientific studies to evaluate the economic profitability of the joint production of timber and NTFP. In general, useful and practical recommendations around how to manage forests in joint production and giving emphasis to NTFPs are rare although several forest planning systems also consider NTFPs [117].

Our review found that yield models exist for a variety of NTFPs that are economically important to forest owners, or those socially, culturally and recreationally valuable NTFPs that can be collected with everyman's rights. Harvesting NTFPs can create significant additional incomes to forest owners, and the joint production of timber and NTFPs can be more profitable than timber production. Timber-oriented forest management, especially with a single tree species and even-aged rotation management, often needs to be modified if the aim is to also explicitly consider NTFPs.

New models and forest management practices are needed for a variety of NTFPs such as tree fruits and nuts, birch sap, a wider variety of edible mushrooms, specialty fungi cultivated on live trees, as well as medicinal and edible forest herbs. The existing yield models for NTFPs are often local and cover only a portion of European regions. Therefore, models for the yield and quality of NTFPs should be further developed to be included in regional and national analyses. Climatesensitive empirical models would allow the prediction of the potential effects of climate change on NTFP yields.

Funding Open access funding provided by Natural Resources Institute Finland (LUKE). Jari Miina and Mikko Kurttila have received part of their salaries from a project that was funded by Natural Resources Institute Finland (Luke). Rafael Calama acknowledges support from PROPINEA agreement CC16-095. Sergio de-Miguel acknowledges support from the project with grant number RTI2018-099315-A-I00, funded by the Spanish Ministry of Science, Innovation and Universities, Government of Spain. Rafael Calama and Sergio de-Miguel acknowledge the project Innovation Networks of Cork, Resins and Edibles in the Mediterranean basin (INCREDIBLE) funded by the European Commission's Horizon 2020 programme under grant agreement $\mathrm{N}^{\circ}$ 774632. Timo Pukkala received no funding for his work on this article.

\section{Compliance with Ethical Standards}

Conflict of Interest The authors declare that they have no conflict of interest. 
Human and Animal Rights and Informed Consent This article does not contain any studies with human or animal subjects performed by any of the authors.

Open Access This article is licensed under a Creative Commons Attribution 4.0 International License, which permits use, sharing, adaptation, distribution and reproduction in any medium or format, as long as you give appropriate credit to the original author(s) and the source, provide a link to the Creative Commons licence, and indicate if changes were made. The images or other third party material in this article are included in the article's Creative Commons licence, unless indicated otherwise in a credit line to the material. If material is not included in the article's Creative Commons licence and your intended use is not permitted by statutory regulation or exceeds the permitted use, you will need to obtain permission directly from the copyright holder. To view a copy of this licence, visit http://creativecommons.org/licenses/by/4.0/.

\section{References}

Papers of particular interest, published recently, have been highlighted as:

- Of importance

•- Of major importance

1.• Vacik H, Hale M, Spiecker H, Pettenella D, Tomé M, editors. Non-wood forest products in Europe. Ecology and management of mushrooms, tree products, understory plants and animal products. Outcomes of the COST Action FP1203 on European NWFPs. Books on Demand GmbH, Norderstedt, Germany; 2020. A comprehensive description of the current state of the art of the European NTFPs, providing analysis of the present situation with suggestions for future innovation.

2.• Wolfslehner B, Prokofieva I, Mavsar R, editors. Non-wood forest products in Europe: seeing the forest around the trees. European Forest Institute. What Science Can Tell Us 10; 2019. A comprehensive description of the current state of the art of the NTFP sector in Europe, providing analysis of the present situation with suggestions for future innovation.

3.• Sheppard JP, Chamberlain J, Agúndez D, Bhattacharya P, Chirwa PW, Gontcharov A, et al. Sustainable forest management beyond the timber-oriented status quo: transitioning to co-production of timber and non-wood forest products - a global perspective. Curr For Rep. 2020; 6:26-40. A comprehensive review on the sustainable management of forests for timber and NTFPs with special attention to property, tenancy, public goods and access rights to NTFPs.

4. Campos P, Caparrós A, Cerdá E, Diaz-Balteiro L, Herruzo AC, Huntsinger L, et al. Multifunctional natural forest silviculture economics revised: challenges in meeting landowners' and society's wants: a review. For Syst. 2017;26(2):eR01S A comprehensive review that accounts for ecosystem services in economic multifunctional forest management, incorporating both private and public product managements.

5. Roces-Díaz JV, Vayreda J, Banqué-Casanovas M, Cusó M, Anton $\mathrm{M}$, Bonet JA, et al. Assessing the distribution of forest ecosystem services in a highly populated Mediterranean region. Ecol Indic. 2018;93:986-97.

6. Roces-Díaz JV, Vayreda J, Banqué-Casanovas M, Díaz-Varela E, Bonet JA, Brotons L, et al. The spatial level of analysis affects the patterns of forest ecosystem services supply and their relationships. Sci Total Environ. 2018;626:1270-83.
7. Lanzas M, Hermoso V, de-Miguel S, Bota G, Brotons L. Designing a network of green infrastructure to enhance the conservation value of protected areas and maintain ecosystem services. Sci Total Environ. 2019;651:541-50.

8. Calama R, Tomé M, Sánchez-González M, Miina J, Spanos K, Palahí M. Modelling non-wood forest products in Europe: a review. For Syst. 2010;19:69-85 A comprehensive review on European NTFP models published before 2010.

9. Pasalodos-Tato M, Pukkala T, Rigueiro-Rodríguez A, FernándezNúñez E, Mosquera-Losada MR. Optimal management of Pinus radiata silvopastoral systems established on abandoned agricultural land in Galicia (North-Western Spain). Silva Fennica. 2009;43:831-45.

10. Calama R, Gordo J, Madrigal G, Mutke S, Conde M, Monteiro G, et al. Enhanced tools for predicting annual stone pine (Pinus pinea L.) cone production at tree and forest scale in Inner Spain. For Syst. 2016;25:e079.

11. Monserud RA, Haynes RW, Johnson AC. Compatible forest management: background and context. In: Monserud RA, Haynes RW, Johnson AC, editors. Compatible forest management. Dordrecht: Kluwer Academic Publ; 2003. p. 3-32.

12. Kurttila M, Pukkala T, Miina J. Synergies and trade-offs in the production of NWFPs predicted in boreal forests. Forests. 2018;9: 417.

13. Aldea J, Martínez-Peña F, Diaz-Balteiro L. Integration of fungal production in forest management using a multi-criteria method. Eur J For Res. 2012;131:1991-2003.

14. Aldea J, Martínez-Peña F, Romero C, Diaz-Balteiro L. Participatory goal programming in forest management: an application integrating several ecosystem services. Forests. 2014;5: 3352-71.

15. Bonet JA, Palahí M, Colinas C, Pukkala T, Fischer CR, Miina J, et al. Modelling the production and species richness of wild mushrooms in pine forests of the Central Pyrenees in northeastern Spain. Can J For Res. 2010;40:347-56.

16. Bonet JA, de-Miguel S, Martínez de Aragón J, Pukkala T, Palahí M. Immediate effect of thinning on the yield of Lactarius group deliciosus in Pinus pinaster forests in northeastern Spain. For Ecol Manag. 2012;265:211-7.

17. Collado E, Camarero JJ, Martínez de Aragón J, Pemán J, Bonet JA, de-Miguel S. Linking fungal dynamics, tree growth and forest management in a Mediterranean pine ecosystem. For Ecol Manag. 2018;422:223-32.

18. Collado E, Bonet JA, Camarero JJ, Egli S, Peter M, Salo K, et al. Mushroom productivity trends in relation to tree growth and climate across different European forest biomes. Sci Total Environ. 2019;689:602-15.

19. de-Miguel S, Bonet JA, Pukkala T, Martínez de Aragón J. Impact of forest management intensity on landscape-level mushroom productivity: a regional model-based scenario analysis. For Ecol Manag. 2014;330:218-27.

20. Hernández-Rodríguez M, de-Miguel S, Pukkala T, Oria-de-Rueda JA, Martín-Pinto P. Climate-sensitive models for mushroom yields and diversity in Cistus ladanifer scrublands. Agric For Meteorol. 2015;213:173-82.

21. Herrero C, Berraondo I, Bravo F, Pando V, Ordóñez C, Olaizola J, et al. Predicting mushroom productivity from long-term field-data series in Mediterranean Pinus pinaster Ait forests in the context of climate change. Forests. 2019;10:206.

22. Karavani A, De Cáceres M, Martínez de Aragón J, Bonet JA, DeMiguel S. Effect of climatic and soil moisture conditions on mushroom productivity and related ecosystem services in Mediterranean pine stands facing climate change. Agric For Meteorol. 2018;248:432-40.

23. Küçüker DM, Bașkent EZ. Spatial prediction of Lactarius deliciosus and Lactarius salmonicolor mushroom distribution 
with logistic regression models in the Kizilcasu planning unit, Turkey. Mycorrhiza. 2015;25:1-11.

24. Küçüker DM, Bașkent EZ. Modeling the productivity of commercial Lactarius mushrooms: a case study in the Kizilcasu planning unit, Turkey. Nat Resour Model. 2019;32:e12178.

25. Liu B, Bonet JA, Fischer CR, Martínez de Aragón J, Bassie L, Colinas C. Lactarius deliciosus Fr. Soil extraradical mycelium correlates with stand fruitbody productivity and is increased by forest thinning. For Ecol Manag. 2016;380:196-201.

26. Martínez-Peña F, Ágreda T, Águeda B, Ortega-Martínez P, Fernández-Toirán LM. Edible sporocarp production by age class in a scots pine stand in northern Spain. Mycorrhiza. 2012;22:16774.

27. Martínez-Peña F, de-Miguel S, Pukkala T, Bonet JA, OrtegaMartínez P, Aldea J, et al. Yield models for ectomycorrhizal mushrooms in Pinus sylvestris forests with special focus on Boletus edulis and Lactarius group deliciosus. For Ecol Manag. 2012;282:63-9.

28. Peura M, Silveyra Gonzalez R, Müller J, Heurich M, Vierling LA, Mönkkönen M, et al. Mapping a 'cryptic kingdom': performance of lidar derived environmental variables in modelling the occurrence of forest fungi. Remote Sens Environ. 2016;186:428-38.

29. Sánchez-González M, de-Miguel S, Martin-Pinto P, MartínezPeña F, Pasalodos-Tato M, Oria-de-Rueda JA, et al. Yield models for predicting aboveground ectomycorrhizal fungal productivity in Pinus sylvestris and Pinus pinaster stands of northern Spain. For Ecosyst. 2019;6:52.

30. Tahvanainen V, Miina J, Kurttila M, Salo K. Modelling the yields of marketed mushrooms in Picea abies stands in eastern Finland. For Ecol Manag. 2016;362:79-88.

31. Taye ZM, Martínez-Peña F, Bonet JA, Martínez de Aragón J, deMiguel S. Meteorological conditions and site characteristics driving edible mushroom production in Pinus pinaster forests of Central Spain. Fungal Ecol. 2016;23:30-41.

32. Vásquez Gassibe P, Fraile Fabero R, Hernández-Rodríguez M, Oria-de-Rueda JA, Bravo Oviedo F, Martín-Pinto P. Post-fire production of mushrooms in Pinus pinaster forests using classificatory models. J For Res. 2014;19:348-56.

33. Ponce RA, Ágreda T, Águeda B, Aldea J, Martínez-Peña F, Modrego MP. Soil physical properties influence "black truffle" fructification in plantations. Mycorrhiza. 2014;24:55-64.

34. Caignard T, Kremer A, Firmat C, Nicolas M, Venner S, Delzon S. Increasing spring temperatures favor oak seed production in temperate areas. Sci Rep. 2017;7:8555.

35. Pérez-Ramos IM, Padilla-Díaz CM, Koenig WD, Marañón T. Environmental drivers of mast-seeding in Mediterranean oak species: does leaf habit matter? J Ecol. 2015;103:691-700.

36. Pereira MG, Caramelo L, Gouveia C, Gomes-Laranjo J, Magalhães M. Assessment of weather-related risk on chestnut productivity. Nat Hazards Earth Syst Sci. 2011;11:2729-39.

37. Almeida AM, Tomé J, Tomé M. Development of a system to predict the evolution of individual tree mature cork caliber over time. For Ecol Manag. 2010;260(8):1303-14.

38. Costa A, Nunes LC, Spiecker H, Graça J. Insights into the responsiveness of cork oak (Quercus suber L.) to bark harvesting. Econ Bot. 2015;69(2):171-84

39. Faias SP, Paulo JA, Palma JHN, Tomé M. Understory effect on tree and cork growth in cork oak woodlands. For Syst. 2018;27(1): $\mathrm{e} 02 \mathrm{~S}$.

40. Faias SP, Paulo JA, Firmino PN, Tomé M. Drivers for annual cork growth under two understory management alternatives on a podzolic cork oak stand. Forests. 2019;10(2):133.

41. Paulo JA, Tomé M. Predicting mature cork biomass with $t$ years of growth from one measurement taken at any other age. For Ecol Manag. 2010;259:1993-2005.
42. Paulo JA, Pereira H, Tomé M. Analysis of variables influencing tree cork caliper in two consecutive cork extractions using cork growth index modelling. Agrofor Syst. 2017;91:221-37.

43. Pizzurro GM, Maetzke F, La Mela Veca DS. Differences of raw cork quality in productive cork oak woods in Sicily in relation to stand density. For Ecol Manag. 2010;260:923-9.

44. Ayanoğlu F, Kaya DA, Bahadirli N. Effects of planting density and harvesting time on leaf and essential oil yield of bay laurel (Laurus nobilis L.) cultured in shrub form. The 7th International Conference on Advanced Materials and Systems, Bucharest, Romania, October 18-20, 2018; p. 289-294.

45. Calama R, Mutke S, Tomé J, Gordo J, Montero G, Tomé M. Modelling spatial and temporal variability in a zero-inflated variable: the case of stone pine (Pinus pinea $\mathrm{L}$.) cone production. Ecol Model. 2011;222:606-18.

46. Rodrigues A, Silva GL, Casquilho M, Freire J, Carrasquinho I, Tomé M. Linear mixed modelling of cone production for stone pine in Portugal. Silva Lusitana. 2014;22(1):1-27.

47. Palma A, Pereira JM, Soares P. Resin tapping activity as a contribution to the management of maritime pine forest. For Syst. 2016;25(2):eSC11.

48. Spanos K, Gaitanis D, Spanos I. Resin production in natural Aleppo pine stands in northern Evia, Greece. Web Ecol. 2010;10:38-43.

49. Rodríguez-García A, López R, Martín JA, Pinillos F, Gil L. Resin yield in Pinus pinaster is related to tree dendrometry, stand density and tapping-induced systemic changes in xylem anatomy. For Ecol Manag. 2014;313:47-54.

50. Rodríguez-García A, Martín JA, López R, Mutke S, Pinillos F, Gil L. Influence of climate variables on resin yield and secretory structures in tapped Pinus pinaster Ait. In Central Spain. Agric For Meteorol. 2015;202:83-93.

51. Rodríguez-García A, Martín JA, López R, Sanz A, Gil L. Effect of four tapping methods on anatomical traits and resin yield in maritime pine (Pinus pinaster Ait.). Ind Crop Prod. 2016;86:143-54.

52. Rodríguez-García A, Madrigal J, González-Sancho D, Gil L, Guijarro M, Hernando C. Can prescribed burning improve resin yield in a tapped Pinus pinaster stand. Ind Crop Prod. 2018;124: 91-8.

53. Kilpeläinen H, Miina J, Store R, Salo K, Kurttila M. Evaluation of bilberry and cowberry yield models by comparing model predictions with field measurements from North Karelia, Finland. For Ecol Manag. 2016;363:120-9.

54. Pukkala T, Lähde E, Laiho O, Salo K, Hotanen J-P. A multifunctional comparison of even-aged and uneven-aged forest management in a boreal region. Can J For Res. 2011;41:851-62.

55. Turtiainen M, Miina J, Salo K, Hotanen J-P. Empirical prediction models for the coverage and yields of cowberry in Finland. Silva Fennica. 2013;47:1005.

56. Turtiainen M, Miina J, Salo K, Hotanen J-P. Modelling the coverage and annual variation in bilberry yield in Finland. Silva Fennica. 2016;50:1573.

57. de-Miguel S, Pukkala T, Yeșil A. Integrating pine honeydew honey production into forest management optimization. Eur J For Res. 2014; 133:423-32.

58. Ion N, Coman R, Ion V. Melliferous potential of silver linden trees (Tilia tomentosa Moench.) growing in the forests from South Romania. Sci Pap Ser A Agron. 2018;LXI(1):474-80.

59. Prešern J, Mihelič J, Kobal M. Growing stock of nectar- and honeydew-producing tree species determines the beekeepers' profit. For Ecol Manag. 2019;448:490-8.

60. Hernández-Rodríguez M, Martín-Pinto P, Oria-de-Rueda JA, Diaz-Balteiro L. Optimal management of Cistus ladanifer shrublands for biomass and Boletus edulis mushroom production. Agrofor Syst. 2017;91:663-76. 
61. Tahvanainen V, Miina J, Pukkala T, Kurttila M. Optimizing the joint production of timber and marketed mushrooms in Picea abies stands in eastern Finland. J For Econ. 2018;32:34-41.

62. Küçüker DM, Bașkent EZ. Sustaining the joint production of timber and Lactarius mushroom: a case study of a forest management planning unit in northwestern Turkey. Sustainability. 2017;9(1): 92.

63. Küçüker DM, Başkent EZ. Impact of forest management intensity on mushroom occurrence and yield with a simulation-based decision support system. For Ecol Manag. 2017;389:240-8.

64. Peura M, Triviño M, Mazziotta A, Podkopaev D, Juutinen A, Mönkkönen M. Managing boreal forests for the simultaneous production of collectable goods and timber revenues. Silva Fennica. 2016;50(5):1672.

65. Peura M, Burgas D, Eyvindson K, Repo A, Mönkkönen M. Continuous cover forestry is a cost-efficient tool to increase multifunctionality of boreal production forests in Fennoscandia. Biol Conserv. 2018;217:104-12.

66. Martins A, Marques G, Borges O, Portela E, Lousada J, Raimundo $\mathrm{F}$, et al. Management of chestnut plantations for a multifunctional land use under Mediterranean conditions: effects on productivity and sustainability. Agrofor Syst. 2011;81:175-89.

67. Pasalodos-Tato M, Pukkala T, Cañellas I, Sánchez-González M. Optimizing the debarking and cutting schedule of cork oak stands. Ann For Sci. 2018;75:61.

68. Paulo JA, Tomé M. Using the SUBER model for assessing the impact of cork debarking rotation on equivalent annual annuity in Portuguese stands. For Syst. 2017;26(1):e008.

69. Costa A, Oliveira AC, Vidas F, Borges JG. An approach to cork oak forest management planning: a case study in southwestern Portugal. Eur J For Res. 2010;129:233-41.

70. von Essen M, do Rosário IT, Santos-Reis M, Nicholas KA. Valuing and mapping cork and carbon across land use scenarios in a Portuguese montado landscape. PLoS One. 2019;14(3): e0212174.

71. Borges JG, Garcia-Gonzalo J, Bushenkov V, McDill ME, Marques S, Oliveira MM. Addressing multicriteria forest management with Pareto frontier methods: an application in Portugal. For Sci. 2014;60(1):63-72.

72. Palma JHN, Paulo JA, Faias SP, Garcia-Gonzalo J, Borges JG, Tomé M. Adaptive management and debarking schedule optimization of Quercus suber L. stands under climate change: case study in Chamusca, Portugal. Reg Environ Chang. 2015;15: 1569-80.

73. Ovando P, Campos P, Calama R, Montero G. Landowner net benefit from stone pine (Pinus pinea L.) afforestation of dryland cereal fields in Valladolid, Spain. J For Econ. 2010;16(2): $83-100$

74. Pardos M, Calama R, Maroschek M, Rammer W, Lexer MJ. A model-based analysis of climate change vulnerability of Pinus pinea stands under multiobjective management in the northern plateau of Spain. Ann For Sci. 2015;72:1009-21.

75. Pasalodos-Tato M, Pukkala T, Calama R, Cañellas I, SánchezGonzález M. Optimal management of Pinus pinea stands when cone and timber production are considered. Eur J For Res. 2016;135:607-19.

76. Pereira S, Prieto A, Calama R, Diaz-Balteiro L. Optimal management in Pinus pinea L. stands combining silvicultural schedules for timber and cone production. Silva Fennica. 2015;49(3):1226.

77. Génova M, Caminero L, Dochao J. Resin tapping in Pinus pinaster: effects on growth and response function to climate. Eur J For Res. 2014;133(2):323-33.

78. Miina J, Pukkala T, Hotanen J-P, Salo K. Optimizing the joint production of timber and bilberries. For Ecol Manag. 2010;259: 2065-71.
79. Miina J, Pukkala T, Kurttila M. Optimal multi-product management of stands producing timber and wild berries. Eur J For Res. 2016;135:781-94.

80. Pukkala T. Which type of forest management provides most ecosystem services? For Ecosyst. 2016;3:9.

81. Eyvindson K, Repo A, Mönkkönen M. Mitigating forest biodiversity and ecosystem service losses in the era of bio-based economy. Forest Policy Econ. 2018;92:119-27.

82. Eyvindson K, Repo A, Triviño M, Pynnönen S, Mönkkönen M. Quantifying and easing conflicting goals between interest groups in natural resource planning. Can J For Res. 2019;49:1233-41.

83. Kilpeläinen H, Salminen O, Härkönen K, Miina J, Kurttila M. Integrating bilberry yields into regional long-term forest scenario analyses. Scand J For Res. 2018;33:378-86.

84. Pohjanmies T, Triviño M, Le Tortorec E, Salminen H, Mönkkönen M. Conflicting objectives in production forests pose a challenge for forest management. Ecosyst Serv. 2017;28:298 310 .

85. Tuunanen P, Tarasti M, Rautiainen A, editors. Everyman's rights and the code of conduct on private land - existing legislation and suggestions for best practices. Ministry of the Environment, Finland. The Finnish Environment 2015; 141 p.

86. Tyrväinen L, Bauer N, O'Brien L. Impacts of forests on human health and well-being. In: Marušáková L, Sallmanshofer M, editors. Human health and sustainable forest management. Liaison Unit Bratislava: Forests Europe; 2019. p. 30-57.

87. Engel S, Pagiola S, Wunder S. Designing payments for environmental services in theory and practice: an overview of issues. Ecol Econ. 2008;65(4):663-74.

88. Gatto P, Pettenella D, Secco L. Payments for forest environmental services: organisational models and related experiences in Italy. iForest. 2009;2:133e139.

89. Górriz-Mifsud E, Secco L, Da Re R, Pisani E, Bonet JA. Structural social capital and local-level forest governance: do they inter-relate? A mushroom permit case in Catalonia. J Environ Manag. 2017;188(1):364-78.

90. Tomé M, Cañellas I, Bonet JA, Paulo JA, Palma JHN, Martínez de Aragón J, Miina J, Sheppard J, Kurttila M, Sánchez-González M, Pasalodos M, de-Miguel S. Resource and management - novel management concepts to boost product diversity and secure higher product flows. In: Wolfslehner B, Prokofieva I, Mavsar R, editors. Non-wood forest products in Europe: seeing the forest around the trees. European forest institute. What Science Can Tell Us 2019; 10: 104-110.

91. Rautiainen M, Miettinen J, Putaala A, Rantala M, Alhainen M. Grouse-friendly forest management in Finland. Unasylva. 2017;68:71-7.

92. Månsson J, Roberge JM, Edenius L, Bergström R, Nilsson L, Lidberg M, et al. Food plots as a habitat management tool: forage production and ungulate browsing in adjacent forest. Wildl Biol. 2015;21:246-53.

93. Calama R, Conde M, De Dios GJ, Madrigal G, Vázquez-Piqué J, Pardos M. Linking climate, annual growth and competition in a Mediterranean forest: Pinus pinea in the Spanish northern plateau. Agric For Meteorol. 2019;264:309-21.

94. Moreno-Fernández D, Cañellas I, Calama R, Gordo J, SánchezGonzález MO. Thinning increases cone production of stone pine (Pinus pinea L.) stands in the northern plateau (Spain). Ann For Sci. 2013;70:761-8.

95. Palahí M, Pukkala T, Bonet JA, Colinas C, Fisher RF, Martínez de Aragón JR. Effect of the inclusion of mushroom values on the optimal management of even-aged pine stands of Catalonia. For Sci. 2009;55:503-11.

96. García-Güemes C, Montero G. Influencia de ciertas variables selvicolas en la pudricion provocada por Phellinus pini sobre 
Pinus pinea. Investig Agrar Sistemas Recur Forestales. 1998;7: 203-18.

97.• Calama R, Miina J, de-Miguel S, Bonet SA, Mounir F, Tomé M, et al. Data \& models: importance of assessing and forecasting nonwood forest products in Europe. In: Vacik H, Hale M, Spiecker H, Pettenella D, Tomé M, editors. Non-wood forest products in Europe. Ecology and management of mushrooms, tree products, understory plants and animal products. Outcomes of the COST Action FP1203 on European NWFPs. Norderstedt: Books on Demand $\mathrm{GmbH} ; 2020$. A comprehensive survey on assessing European NTFPs.

98. Pasalodos-Tato M, Alberdi I, Cañellas I, Sánchez-González M. Towards assessment of cork production through National Forest Inventories. Forestry. 2018;91:110-20.

99. Vauhkonen J. Predicting the provisioning potential of forest ecosystem services using airborne laser scanning data and forest resource maps. For Ecosyst. 2018;5:24.

100. Schneider R, Calama R, Martin-Ducup O. Understanding tree-totree variations in stone pine (Pinus pinea $\mathrm{L}$.) cone production using terrestrial laser scanner. Remote Sens. 2020;12(1):173.

101. Reyna S, Garcia-Barreda S. Black truffle cultivation: a global reality. For Syst. 2014;23:317-28.

102. Tomao A, Bonet JA, Martínez de Aragón J, de-Miguel S. Is silviculture able to enhance wild forest mushroom resources? Current knowledge and future perspectives. For Ecol Manag. 2017;402: 102-14 A comprehensive review on silvicultural effects on mushrooms with special attention to promoting the production of wild edible mushrooms.

103. Mutke S, Calama R, González-Martínez SC, Montero G, Gordo FJ, Bono D, Gil L. Mediterranean stone pine: botany and horticulture. In: Janick J, editor. Horticulture reviews. New York: Wiley; 2012; 39(1):153-201.

104. del Río M, Barbeito, I, Bravo-Oviedo A, Calama R, Cañellas I, Herrero C, Montero G, Moreno-Fernández D, Ruiz-Peinado R, Bravo F. Mediterranean pine forests: Management effects on carbon stocks. In: Bravo F, LeMay V, Jandl R, von Gadow K, editors. Managing forest ecosystems: The challenge of climate change; Kluwer Academic Publ; 2017. p. 301-327.

105. Shackleton CM, Pandey AK, Ticktin T. Ecological sustainability for non-timber Forest products: dynamics and case studies of harvesting. London: Routledge; 2015.
106. Angelsen A, Jagger P, Babigumira R, Belcher B, Hogarth NJ, Bauch S, et al. Environmental income and rural livelihoods: a global-comparative analysis. World Dev. 2014;64:12-28.

107. Ribeiro do Valle D, Staudhammer CL, Cropper WP Jr. Simulating nontimber forest product management in tropical mixed forests. J For. 2007;105:301-6.

108. Jin X, Li F, Pukkala T, Donga L. Modelling the cone yields of Korean pine. For Ecol Manag. 2020;464:118086.

109. Stiti B, Chaar H, Khaldi A, Henchi B. Analysis and modelling of cork production towards an optimal management: case of Ain Snoussi forest, northwestern Tunisia. J New Sci Agric Biotechnol. 2019;65(4):4088-95.

110. Lee YF. Some models for estimating rattan growth and yield. J Trop For Sci. 1994;6(3):346-55.

111. Muchiri MN, Muga MO. A preliminary yield model for natural Yushania alpina bamboo in Kenya. J Nat Sci Res. 2013;3:77-84.

112. Sangma W, Jumroonrut S. Generalized estimating equations models for rubber yields in Thailand. Int J Appl Eng Res. 2017;12(17):6347-53.

113. Risio L, Calama R, Bogino S, Bravo F. Inter-annual variability in Prosopis caldenia pod production in the Argentinean semiarid pampas: a modelling approach. J Arid Environ. 2016;131:59-66.

114. DeVetter L, Colquhoun J, Zalapa J, Harbut R. Yield estimation in commercial cranberry systems using physiological, environmental, and genetic variables. Sci Hortic. 2015;190:83-93.

115. Nayak S, Sahoo S, Singh S. Medicinal plants: towards optimization and prediction of drug yield. Saarbrücken: Lambert Academic Publishing; 2018.

116. Duchesne L, Houle D. Interannual and spatial variability of maple syrup yield as related to climatic factors. Peerj. 2014;2:e428.

117. Kurttila M, Tahvanainen V, editors. Description of new decision support tools for optimization of MPT and NWFP management. Deliverable 2.4. FP7 Project no 311919 KBBE.2012.1.2-06, European Commission, 2016; p. 106

Publisher's Note Springer Nature remains neutral with regard to jurisdictional claims in published maps and institutional affiliations. 